\title{
STRATEGI PENGEMBANGAN EKOWISATA HUTAN MANGROVE DI KAWASAN PANTAI OESAPA
}

\author{
Novalina Sagala ${ }^{1 *}$, Imelda Regina Pellokila, SE.,MM ${ }^{2}$ \\ 1,2 Jurusan Pariwisata, Politeknik Negeri Kupang \\ Jl. Adisucipto Kampus Penfui-Kupang NTT \\ E-mail: sagalanova2011@gmail.com
}

\begin{abstract}
Abstrak
Hutan mangrove di kawasan Pantai Oesapa Barat memiliki keunikan daya tarik tersendiri karena menawarkan atraksi wisata yang berbeda dari objek wisata lainya yaitu hutan mangrove dan hingga saat ini masih merupakan satu-satunya ekowisata hutan mangrove yang ada di Kota Kupang, yang dikelola oleh pemerintah kota kupang, dengan memberdayakan masyarakat lokal sebagai pelaku utama dalam menyajikan atraksi wisata yang ada. Namun seiring berjalanya waktu pengunjung yang datang mengunjungi objek wisata ini menurun. Dalam pengembangan objek wisata hutan mangrove terdapat halangan didalamnya diantaranya,kurangnya atraksiwisata pendukung, kurangnya sadar wisata dari masyarakat setempat, kurangnya kegiatan penanaman mangrove yang merupakan potensi objek wisata tersebut, sehingga perlu adanya pembinaan, pelatihan, penyuluhan terhadap masyarakat tentang pentingnya pengembangan potensi wisata yang ada. Metode penelitian yang dipakai dalam penelitian ini adalah kuantitatif dengan pengumpulan populasi dan menggunakan teknik purposive sampling untuk menentukan sampel dan adanya penyebaran kuisioner kepada wisatawan yang berkunjung ke objek wisata. Data yang dikumpulkan diolah menggunakan metode analisis SWOT, IFAS dan EFAS.

Hasil penelitian kondisi objek wisata hutan mangrove secara keseluruhan dari segi fisiknya masih perlu sentuhan, perhatian dan pembangunan yang lebih lagi, baik itu dari pihak pemerintah yang bersangkutan maupun dari pihak pengelola dan masyarakat setempat. Berdasarkan hasil analisis SWOT langkah yang dapat dirumuskan dengan menggunakan kekuatan dan memanfaatkan peluang yaitu adanya kerja sama pihak pemerintah dan komunitas pariwisata lainya yang memanfaatkan potensi yang tersedia. Memanfaatkan atraksi yang tersedia dan menambahkan atraksi pendukung, memberdayakan masyarakat lokal, dan memanfaatkan lokasi untuk dijadikan tempat usaha pariwisata.
\end{abstract}

Kata Kunci : Strategi Pengembangan, Ekowisata

\section{PENDAHULUAN}

\subsection{Latar Belakang}

Indonesia memiliki potensi keindahan dan kekayaan alam yang bernilai tinggi dalam pasar industri wisata alam, khususnya ekowisata. Sebagai bentuk wisata yang sedang trend, ekowisata mempunyai kekhususan tersendiri yaitu mengedepankan konservasi lingkungan, pendidikan lingkungan, kesejahteraan penduduk lokal dan menghargai budaya lokal.

Dalam beberapa tahun terakhir ini pertumbuhan ekowisata sangat pesat. Hal ini disebabkan oleh banyak negara membuat promosi dan atraksi ekowisata besar-besaran dalam rangka meraup manfaat dan kesempatan dalam pasar ekowisata yang terus tumbuh. Berdasarkan laporan World Travel Tourism Council (WTTC) tahun 2000, pertumbuhan rata-rata ekowisata sebesar $10 \%$ pertahun. Angka tersebut lebih tinggi dibanding rata-rata pertahun untuk pariwisata pada umumnya yaitu sebesar $40 \%$ di Eropa dan Amerika Latin dan 25\% di Asia Pasifik.

Indonesia memiliki mangrove (bakau) yang terluas di dunia dan juga memiliki keragaman hayati yang terbesar serta strukturnya paling bervariasi. $\mathrm{Di}$ Indonesia perkiraan luas mangrove juga sangat beragam. Giesen (1993) menyebutkan luas mangrove Indonesia sekitar 2,5 hingga 4,5 juta hektar. Hutan mangrove sebagai sumber daya alam hayati mempunyai keragaman potensi yang memberikan manfaat bagi kehidupan manusia. Pemanfaatan produk dan jasa telah memberikan tambahan pendapatan dan bahkan merupakan penghasilan utama dalam pemenuhan kebutuhan hidup masyarakat.

Salah satu jasa yang diperoleh dari manfaat hutan mangrove adalah berupa jasa ekowisata (Kustanti dkk., 2005). Hutan mangrove sebagai suatu ekosistem mempunyai potensi keindahan alam dan lingkungan berupa komponen penyusun ekoistem yang terdiri dari vegetasi, biota atau 
organisme asosiasi, satwa liar, dan lingkungan sekitarnya.

Disamping itu hutan mangrove merupakan areal tempat penelitian, pendidikan, dan ekowisata (Massaut 1999 dan FAO 1994). Dengan berpedoman tujuan utama, yaitu tercapainya pembangunan yang berkelanjutan yang berwawasan lingkungan. Salah satu daerah di Indonesia yang memiliki kekayaan alam adalah Propinsi Nusa Tenggara Timur (NTT). Di antara potensi itu adalah wisata bahari, wisata alam, wisata budaya dan kerajinan yang tersebar di beberapa pulau. Salah satunya adalah ekowisata mangrove yang terletak di kawasan pantai oesapa barat, kota kupang.

Objek wisata hutan mangrove di kawasan pantai Oesapa barat ini, hingga saat ini masih merupakan satu-satunya ekowisata hutan mangrove yang ada di kota Kupang, yang di kelola oleh pemerintah kota kupang. Salah satu yang menjadi unggulan di destinasi ini tentunya adalah pemandangan alam dengan lebatnya mangrove beserta biota-biota baik khas mangrove maupun fauna yang berasosiasi dengan mangrove yang dapat di nikmati dengan berkeliling melalui jembatan yang telah disiapkan oleh pihak pengelola. Di area hutan mangrove ini juga terdapat tambak garam yang juga merupakan salah satu atraksi di destinasi ini.

Namun seiring berjalannya waktu pengelolaan pada hutan mangrove ini dapat dikatakan kurang maksimal, seperti tidak adanya penambahan penanaman pohon mangrove, semakin berkurang/rusaknya sarana dan prasarana dan pembangunan yang bergerak ditempat sehingga berdampak pada jumlah kunjungan wisatawan pada destinasi ini. Tabel 1.

Data kunjungan wisatawan pada objek wisata hutan mangrove Dikawasan Pantai Oesapa selama bulan Januari - Agustus 2018.

\begin{tabular}{|c|c|}
\hline Bulan & Jumlah \\
\hline Januari & 531 \\
\hline Februari & 813 \\
\hline Maret & 800 \\
\hline April & 213 \\
\hline Mei & 312 \\
\hline Juni & 223 \\
\hline Juli & 753 \\
\hline Agustus & 300 \\
\hline Total & $\mathbf{5 . 1 4 5}$ \\
\hline
\end{tabular}

Sumber: kantor kelurahan Oesapa 2018

Data kunjungan di atas menunjukkan bahwa kunjungan wisatawan pada objek wisata hutan mangrove menurun.

\subsection{Rumusan Masalah}

Adapun rumusan masalah dalam penelitian ini antara lain :

a. Bagaimanakah potensi ekosistem Hutan Mangrove di Pantai Oesapa sebagai daya tarik ekowisata?

b. Bagaimanakah bentuk strategi pengembangan yang tepat untuk ekowisata Mangrove di Kawasan Pantai Oesapa?

\subsection{Tujuan dan Manfaat Penelitian}

1.3.1 Tujuan Penelitian

Adapun tujuan dari penelitian ini diantaranya :

a. Mengidentifikasi potensi ekosistem mangrove pantai oesapa sebagai daya tarik ekowisata.

b. Menentukan strategi pengembangan pada ekowisata mangrove pantai oesapa.

\subsubsection{Manfaat Penelitan}

1. Penelitian ini dapat menambah pengetahuan dan wawasan mengenai cara pengembangan potensi hutan mangrove sebagai daya tarik ekowisata.

2. Penelitian ini diharapkan dapat memberikan masukan kepada pihak pengelola dan dapat menjadi wadah informasi tentang strategi pengembangan pada ekowisata hutan mangrove di kawasan pantai Oesapa sehingga dapat menarik wisatawan untuk berkunjung sehingga dapat memberikan dampak dan manfaat yang dapat dirasakan oleh baik pengelola dan masyarakat yang ada di kawasan ekowisata hutan mangrove tersebut.

\section{TINJAUAN PUSTAKA}

\subsection{Landasan Teori}

\subsubsection{Pengertian Pariwisata}

Pariwisata adalah aktivitas perjalanan yang dilakukan untuk sementara waktu dari tempat tinggal semula ke daerah tujuan dengan alasan bukan untuk menetap atau mencari nafkah melainkan hanya untuk bersenangsenang. Menurut Undang-undang No. 9 Tahun 1990 tentang kepariwisataan menyatakan pariwisata sebagai segala sesuatu yang berhubungan dengan wisata, termasuk pengusahaan objek dan daya tarik serta usahausaha yang terkait dibidang tersebut.

Kepariwisataan mempunyai peranan penting untuk memperluas dan meratakan kesempatan berusaha dan lapangan kerja, mendorong pembangunan daerah, memperbesar pendapatan nasional dalam rangka meningkatkan kesejahteraan dan kemakmuran rakyat serta memupuk rasa cinta 
tanah air, memperkaya kebudayaan nasional dan memantapkan pembinaannya dalam memperkukuh jati diri bangsa (Damanik dan Weber, 2006).

Dorongan kepergiannya adalah karena berbagai kepentingan, baik karena kepentingan ekonomi, sosial, kebudayaan, politik, agama, kesehatan maupun kepentingan lain seperti karena sekedar ingin tahu, menambah pengalaman ataupun sekedar untuk belajar. Ecotourism Research Group (1996) dalam Utama (2009), mendeskripsikan bahwa yang membatasi tentang wisata bertumpu pada lingkungan alam dan budaya yang terkait dengan :

a) Mendidik tentang fungsi dan manfaat lingkungan,

b) Meningkatkan kesadaran lingkungan,

c) Bermanfaat secara ekologi, sosial dan ekonomi,

d) Menyumbang langsung pada keberkelanjutan.

Soemarwoto (2006) dan Utomo(2009), menjelaskan bahwa ekowisata tidak terbatas pada objek alam, tetapi juga mencakup pula kebudayaan. Interaksi lingkungan hidup dengan manusia menciptakan pola hidup seperti yang ada di suatu tempat, namun kebudayaan manusia di tempat tersebut tercipta dari interaksi itu juga. Secara keseluruhan tidak ada yang membedakan antara pariwisata, wisata dan ekowisata, pembeda yang nyata adalah ruang dan waktu pelaksanaan wisata tersebut, karena dalam penyelenggaraan suatu kegiatan satu komponen dengan yang lainnya saling berkaitan dan mendukung, sehingga penyelenggaraan wisata dapat berjalan dengan baik.

\subsubsection{Wisata Bahari}

Wisata Bahari adalah suatu kunjungan ke objek wisata, khususnya untuk menyaksikan keindahan lautan, menyelam dengan perlengkapan selam lengkap (Yoeti, 1996). Pengertian lain dari wisata bahari ini adalah sebuah kegiatan wisata yang berkaitan dengan laut, pantai dan danau. Selain ekosistem laut yang ditawarkan sebagai daya tarik wisata, saat ini telah dikemas berbagai event yang diselenggarakan di laut, pantai dan wilayah sekitarnya antara lain :

a) Olah raga air, acara yang didukung oleh peralatan modern seperti speedboat, Diving, Snorkling, berselancar dan lainlain.

b) Tradisional, acara yang diselenggarakan yang didasarkan pada adat dan budaya masyarakat setempat misalnya pesta nelayan yaitu suatu ritual sebagai bentuk syukur atas berlimpahnya hasil tangkapan ikan.

c) Ekonomi Edukatif, bisa berupa kunjungan ke tempat pelelangan ikan, melihat proses penarikan jaring dari laut oleh nelayan.

d) Kuliner, sebagai suatu tempat yang khas, laut tentu saja menyajikan makanan yang bertemakan olahan hasil laut segar hal ini merupakan salah satu daya tarik wisata bahari.

e) Ekowisata bahari, menyajikan ekosistem alam khas laut berupa hutan mangrove, taman laut serta fauna baik fauna dilaut maupun sekitar pantai.

\subsubsection{Ekowisata}

Ekowisata merupakan perjalanan wisata ke suatu lingkungan baik alam yang alami maupun buatan serta budaya yang ada yang bersifat informatif dan partisipatif yang bertujuan untuk menjamin kelestarian alam dan sosial-budaya. Ekowisata menitikberatkan pada tiga hal utama yaitu; keberlangsungan alam atau ekologi, memberikan manfaat ekonomi, dan secara psikologi dapat diterima dalam kehidupan sosial masyarakat.

Ekowisata merupakan salah satu produk pariwisata alternatif yang mempunyai tujuan membangun pariwisata berkelanjutan yaitu pembangunan pariwisata yang secara ekologis memberikan manfaat yang layak secara ekonomi dan adil secara etika, serta memberikan manfaat sosial terhadap masyarakat.

Salah satu bentuk ekowisata yang dapat melestarikan lingkungan yakni dengan ekowisata mangrove. Mangrove sangat potensial bagi pengembangan ekowisata karena kondisi mangrove yang sangat unik serta model wilayah yang dapat dikembangkan sebagai sarana wisata dengan tetap menjaga keaslian hutan serta organisme yang hidup di kawasan mangrove.

\subsubsection{Ekowisata Mangrove}

Hutan mangrove adalah sebutan umum yang digunakan untuk menggambarkan suatu varietas komunitas pantai tropik yang didominasi oleh beberapa spesies pohon yang khas atau semak-semak yang mempunyai kemampuan untuk tumbuh dalam perairan asin (Nybakken, 1992). Ekowisata merupakan paket perjalanan menikmati keindahan lingkungan tanpa merusak eksosistem hutan yang ada.

Ekowisata mangrove adalah kawasan yang diperuntuhkan secara khusus untuk dipelihara untuk kepentingan pariwisata. Kawasan hutan mangrove adalah salah satu kawasan pantai yang memiliki keunikan dan kekhasan tersendiri, karena keberadaan ekosistem ini berada pada muara sungai atau 
estuaria. Mangrove hanya tumbuh dan menyebar pada daerah tropis dan subtropis dengan kekhasan organisme baik tumbuhan yang hidup dan berasosiasi disana.

Potensi ekowisata merupakan semua objek (alam, budaya, buatan) yang memerlukan banyak penanganan agar dapat memberikan nilai daya tarik bagi wisatawan (Damanik dan weber, 2006).

Ekowisata saat ini menjadi salah satu pilihan dalam mempromosikan lingkungan yang khas yang terjaga keasliannya sekaligus menjadi suatu kawasan kunjungan wisata. Potensi yang ada adalah suatu konsep pengembangan lingkungan yang berbasis pada pendekatan pemeliharaan dan konservasi alam, mangrove sangat potensial bagi pengembangan ekowisata karena kondisi mangrove yang sangat unik serta model wilayah yang dapat di kembangkan sebagai sarana wisata dengan tetap menjaga keaslian hutan serta organisme yang hidup dikawasan mangrove.

Beberapa parameter lingkungan yang dijadikan sebagai potensi pengembangan ekowisata mangrove adalah kerapatan jenis mangrove, ketebalan mangrove, spesies mangrove, kekhasan, pasang surut dan objek biota yang ada didalam ekosistem mangrove.

1) Jenis atau spesies Mangrove

Hutan Mangrove meliputi pohon dan semak yang terdiri dari 12 genera tumbuhan berbunga (Avicennia , Sonneratia , Rhizophora, Bruguiera , Ceriops , Xylocarpus , Lumnitzera , Laguncularia , Aegiceras, Aegiatilis , Snaeda dan Conocarpus ) yang termasuk ke dalam delapan famili (Bengen, 2004). Vegetasi hutan mangrove di Indonesia memiliki keanekaragaman jenis yang tinggi, namun demikian hanya terdapat kurang lebih 47 jenis tumbuhan yang spesifik hutan mangrove. Paling tidak di dalam hutan mangrove terdapat salah satu jenis tumbuhan sejati penting/dominan yang termasuk kedalam empat famili: Rhizophoraceae, (Rhizophora , Bruguiera dan Ceriops), Sonneratiaceae (Sonneratia), Avicenniaceae (Avicennia) dan Meliaceae (Xylocarpus ) (Bengen, 2004).

\section{2) Kerapatan Hutan Mangrove}

Kerapatan jenis adalah jumlah total individu spesies per luas petak pengamatan dimana luas petak pengamatan adalah jumlah plot atau luas plot 28 misalnya jumlah plot yang diamati ada 10 buah, dengan luas masingmasing plot $10 \mathrm{~m} \times 10 \mathrm{~m}$ maka total seluruh petak pengamatan adalah $1000 \mathrm{~m}$ (Fachrul M. F., 2006).

\section{3) Biota Hutan Mangrove}

Menurut Bengen (2004), komunitas fauna hutan mangrove membentuk percampuran antara dua kelompok yaitu :

a. Kelompok fauna daratan / terestrial yang umumnya menempati bagian atas pohon mangrove, terdiri atas: insekta, ular, primata, dan burung. Kelompok ini tidak memiliki sifat adaptasi khusus untuk hidup di dalam hutan mangrove.

b. Kelompok fauna perairan/akuatik, terdiri atas dua tipe yaitu : Yang hidup di kolom air, terutama barbagai jenis ikan, dan udang; Yang menempati substrat baik keras (akar dan batang pohon mangrove maupun lunak (lumpur), terutama kepiting, kerang dan berbagai jenis avertebrata lainnya.

c. Komunitas mangal bersifat unik, disebabkan luas vertikal pohon, dimana organisme daratan menempati bagian atas sedangkan hewan lautan menempati bagian bawah.

\subsubsection{Strategi Pengembangan Pariwisata}

Berdasarkan Kamus Besar Bahasa Indonesia (KBBI), pengertian pengembangan adalah hal, cara atau hasil mengembangkan proses atau cara, perbuatan mengembangkan ke sasaran yang dikehendaki.

Dalam Undang-Undang R1 No 10 Tahun 2009 Pasal 6 dan 7, tentang pembangunan pariwisata disebutkan bahwa pembangunan pariwisata haruslah memperhatikan keanekaragaman, keunikan dan kekhasan budaya dan alam serta kebutuhan manusia untuk berwisata (Pasal 6). Pembangunan pariwisata meliputi industri pariwisata, destinasi pariwisata, pemasaran dan kelembagaan pariwisata (Pasal 7). Menurut Sunaryo (2013:159) pengembangan pariwisata harus mencakup komponen komponen utama sebagai berikut:

a. Objek dan daya tarik, yang mencakup daya tarik yang biasa berbasis utama pada kekayaan alam, budaya, maupun buatan/artificial, seperti event atau yang sering disebut sebagai minat khusus (special interest).

b. Aksesibilitas, yang mencakup dukungan sistem transportasi yang meliputi: rute atau jalur transportasi, fasilitas terminal, bandara, pelabuhan, moda transportasi lain.

c. Amenitas, yang mencakup fasilitas penunjang dan pendukung wisata yang meliputi: akomodasi, rumah makan (food and beverage), retail, toko cinderamata, fasilitas penukaran uang, biro perjalanan, pusat informasi wisata, dan fasilitas kenyamanan lainnya. 
d. Fasilitas pendukung, yaitu ketersediaan fasilitas pendukung yang digunakan oleh wisatawan, seperti bank, rumah sakit, dan sebagainya.

e. Kelembagaan, yaitu keterkaitan dengan keberadaan dan peran masing-masing unsur dalam mendukung terlaksananya kegiatan pariwisata termasuk masyarakat setempat sebagai tuan rumah.

Sebuah destinasi dapat dikatakan akan melakukan pengembangan jika sebelumnya sudah ada aktivitas wisata. Ada beberapa strategi dalam pengembangan pariwisata (Nurhadi, dkk:2013):

a) Pengembangan sarana dan prasarana Wisatawan adalah orang yang suka bepergian sementara waktu ke tempat atau daerah yang sama sekali masih asing baginya. Oleh karena itu sebelum seorang wisatawan melakukan perjalananya sebaiknya terlebih dahulu disediakannya sarana dan prasarana seperti fasilitas transportasi, fasilitas akomodasi, fasilitas chatering service, objek dan atraksi wisata, aktivitas rekreasi, fasilitas perbelanjaan.

b) Strategi promosi

Kegiatan promosi merupakan bagian yang tidak boleh lepas dari proses pengembangan pariwisata. Keberhasilan proses pengembangan pariwisata salah satunya dilakukan oleh kepiawaian Dinas Pariwisata dan Kebudayaan dalam mepromosikan potensi yang dimiliki daerahnya(Shanti, 2010).

\subsubsection{Pengembangan Ekowisata}

\section{a. Lingkungan}

Definisi maupun prinsip-prinsip ekowisata mempunyai implikasi langsung kepada wisatawan dan penyedia jasa perjalanan wisatawan. Wisatawan dituntut untuk tidak hanya mempunyai kesadaran lingkungan dan kepekaan sosial budaya yang tinggi, tetapi mereka harus mampu melakukannya dalam kegiatan wisata melalui sifat-sifat empati wisatawan, digugah untuk mengeluarkan pengeluaran ekstra untuk pelestarian alam.

b. Partisipasi dan Pemberdayaan

Pendekatan partisipasi

pemberdayaan masyarakat setempat pengembangan ekowisata, harus mampu menghasilkan model partisipasi masyarakat. Partisipasi masyarakat setempat dilibatkan dalam penyusunan perencanaan sejak awal, dimana masyarakat dapat menyampaikan gagasan yang dapat memberikan nuansa Participatory Planning, dan harapan yang berbeda dalam melakukan perjalanan wisata.

Pendekatan yang berkesinambungan tersebut, mengingatkan kepada para pelaku yang terkait alam pengembangan ekowisata untuk senantiasa mengendalikan diri, mempertimbangkan manfaat untuk melestarikan alam dan lingkungannya serta keseimbangan budaya yang pada gilirannya secara menyeluruh pada tingkat lokal, regional, nasional dan internasional, termasuk masyarakat penduduk asli.

c. Pengembangan Infrastruktur

Penyediaan infrastruktur dasar adalah merupakan kegiatan penting untuk memperkuat pengembangan ekowisata. Jalan, jembatan, air bersih, jaringan telekomunikasi, listrik dan sistem pengendalian dan pemeliharaan lingkungan, merupakan unsur fisik yang dibangun dengan cara menghindari perusakan lingkungan atau menghilangkan ranah keindahan pada lokasi ekowisata. Teknologi tinggi harus mampu menghindari kerusakan lingkungan dan kerusakan pemandangan yang bertolak belakang dengan konfigurasi alam sekitarnya.

\subsection{Kerangka Berpikir}

Strategi pengembangan menghendaki pemenuhan kebutuhan generasi saat ini maupun generasi mendatang. Strategi pengembangan dan pengelolaan hutan mangrove membutuhkan penanganan secara holistik dan terintegrasi antar dimensi. Konsep strategi pengembangan melalui analisis SWOT (strength. Weaknesses, opportunities, thereats) yang mengidentifikasi strategi untuk pengembangan hutan mangrove.

Gambar 1 : Kerangka berpikir

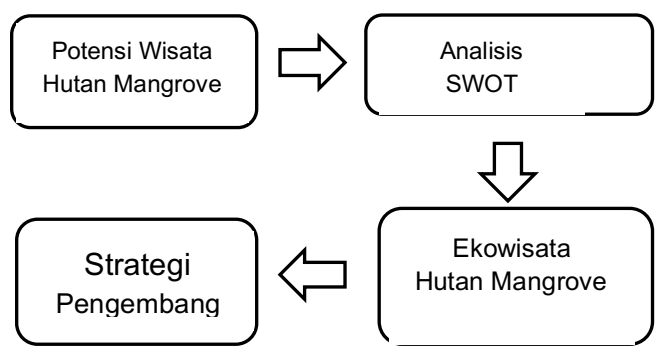

\section{METODE PENILITIAN}

\subsection{Jenis Penelitian}

Jenis penelitian yang digunakan adalah penelitian kuantitatif yaitu suatu proses menemukan pengetahuan yang menggunakan data berupa angka sebagai alat menganalisis keterangan mengenai apa yang ingin diketahui (Kasiram, 2008).

\subsubsection{Jenis dan Sumber Data}

a. Jenis Data

Sugiyono (2010:107) menyatakan bahwa secara garis besar jenis data yang digunakan dalam penelitian dapat dikelompokan menjadi 2 jenis yaitu:

1) Data Kualitatif 
Merupakan data yang diperoleh berupa informasi baik secara lisan maupun tulisan. Data diperoleh dari hasil wawancara, observasi dan data kepustakaan.

2) Data Kuantitatif

Merupakan data yang diperoleh dalam bentuk angka-angka yang dapat dihitung. Data ini diperoleh dari kuisioner yang akan dibagikan dan berhubungan dengan masalah yang akan diteliti. Menggunakan analisis IPA dengan perhitungan skala likert sebagai berikut:

5 = Sangat Penting

$4=$ Penting

3 = Cukup Penting

2 = Tidak Penting

1 = Sangat Tidak Penting

b. Sumber Data

1) Data Primer

Menurut S. Nasution (dalam Malelong, 2010:157) data primer adalah data yang dapat diperoleh langsung dari lapangan atau tempat penelitian. Sedangkan menurut Lofland bahwa sumber data utama dalam penelitian kualitatif ialah kata-kata dan tindakan.

2) Data Sekunder

Data sekunder adalah data-data yang didapat dari sumber bacaan dan berbagai macam sumber lainnya yang terdiri dari surat pribadi, buku harian, notulan rapat, sampai dokumen resmi dari berbagai instansi pemerintah (Malelong, 2010:159).

\subsection{Poulasi dan Sampel}

Populasi adalah wilayah generalisasi yang terdiri dari objek atau subjek yang memiliki kuantitas dan karakteristik tertentu yang diterapkan oleh peneliti untuk di pelajari kemudian ditarik kesimpulan (Sugiyono, 2013;11) maka yang menjadi populasi dalam penelitian ini adalah pihak pengelola, masyarakat sekitar daerah wisata dan wisatawan yang datang berkunjung ke objek wisata tersebut.

Sebagian dari jumlah karakteristik dari jumlah yang dimiliki oleh populasi tersebut, (Sugiyono, 2013 : 11). Pengambilan sampel dalam penelitian ini dengan teknik purposive sampling. Purposive sampling adalah proses pengambilan data dengan pertimbangan tertentu. Pertimbangan tertentu misalnya orang-orang yang tahu betul tentang apa yang kita harapkan, orang-orang tersebut yaitu dari pihak pengelola obyek wisata dan masyarakat sekitar daerah obyek wisata.

Besarnya sampel dalam penelitian ini ditentukan dengan rumus solvin dengan pertimbangan bahwa populasi berhubungan langsung dengan homogen sehingga tidak terlalu di perlukan distratifikasi. Selain itu, penggunaan rumus ini akan dihasilkan sampel yang relative lebih besar sehingga karakteristik dari populasi akan lebih terwakili. Rumus selengkapnya sebagai berikut.

Dimana :

$$
n=\frac{N}{1+N e^{2}}
$$

$\mathrm{n}=$ ukuran sampel

$\mathrm{N}=$ ukuran populasi

$\mathrm{e}=$ persen kelonggaran ketidaktelitian dari kesalahan sampel yang dapat ditolerir atau diingingkan misalnya 10\% (sugiyono 2011:87) jika populasi 300 orang yang ditetapkan atau tingkat signifikasi 0,1 maka besar sample dari penelitian ini adalah

$$
\begin{aligned}
& n=\frac{N}{1+N e^{2}} \\
& n=\frac{300}{1+300(10 \%)^{2}} \\
& n=\frac{300}{1+300(0,1)} \\
& n=\frac{300}{1+3} \\
& n=75
\end{aligned}
$$

Jadi, jumlah dari keseluruhan responden dari penelitian ini adalah 75 , alasan menggunankan rumus tersebut adalah untuk mendapatkan sampel yang representative dan lebih pasti atau mendekati populasi yang ada.

\subsubsection{Teknik Pengumpulan Data}

a. Observasi Partisipatif

Observasi adalah kegiatan pengumpulan data dengan melakukan penelitian langsung terhadap kondisi lingkungan objek penelitian yang mendukung kegiatan penelitian, sehingga didapat gambaran secara jelas tentang kondisi objek penelitian tersebut (Siregar, 2013).

b. Wawancara

Wawancara merupakan proses memperoleh keterangan untuk tujuan penelitian dengan cara tanya jawab dan bertatap muka antara pewawancara dan informan. Adapun teknik pengumpulan data dengan cara wawancara dalam penelitian ini adalah wawancara mendalam. Wawancara mendalam (in-depth interview) adalah data yang diperoleh terdiri dari kutipan secara langsung dari orang-orang tentang pengalaman, pendapat perasaan dan pengetahuan informan penelitian.

c. Studi Kepustakan

Menurut Sugiyono (2011:291) terdapat tiga kriteria yang digunakan sebagai landasan dalam penelitian, yaitu relevansi, kemutakhiran, dan keaslian. Pengumpulan data ini diperoleh dari bebagai referensi yang relevan dengan penelitian yang dijalanakan dan teknik ini 
berdasarkan text book ataupun jurnal ilmiah tentang ekowisata maupun berkaitan dengan strategi pengembangan pariwisata.

d. Kuisioner

Kuisioner adalah teknik pengumpulan data yang dilakukan dengan cara memberi seperangkat pertanyaan atau peryataan tertulis kepada responden untuk dijawab (Sugiyono 2012:199).Kuesioner yang digunakan dalam penelitian ini adalah kuesioner dengan model Skala Likert.

\subsection{Teknik Analisis Data}

\subsubsection{Analisis SWOT}

Analisis SWOT merupakan teknik historis yang terkenal dimana para pemimpin menciptakan gambaran umum secara cepat mengenai situasi strategis organisasi. Analisis ini didasarkan pada asumsi bahwa strategi yang efektif diturunkan dari "kesesuaian" yang baik antara sumber daya organisasi (kekuatan dan kelemahan) dengan situasi eksternalnya (peluang dan ancaman). Kesesuaian yang baik akan memaksimalkan kekuatan dan peluang organisasi serta meminimalkan kelemahan dan ancaman jika diterapkan secara akurat.

Kekuatan (Strenghts) merupakan faktorfaktor kekuatan yang dimiliki oleh suatu organisasi yang meliputi ketrampilan, produk dan sebagainya untuk mencapai tujuan organsisasi. Kelemahan (weaknesses) yang terdapat dalam tubuh suatu organisasi seperti keterbatasan dalam hal sumber, ketrampilan dan kemampuan yang menjadi penghalang serius bagi penampilan kinerja organisasi yang memuaskan. Peluang (Opportunities) merupakan sebagian situasi lingkungan yang mengutungkan bagi suatu perusahaan. Sedangkan ancaman (Threats) merupakan faktor lingkungan yang tidak menguntungkan.

\subsubsection{Matriks EFAS dan IFAS}

David menjelaskan matriks EFAS (External Strategy Factor Analysis Summary) merupakan alat yang digunakan untuk mendaftar serta mengevaluasi ancaman dan kesempatan (treath and opportunity) yang ada pada lingkup eksternal organisasi atau perusahaan.

Matriks IFAS (Internal Strategic Factor Analysis Summary, merupakan alat yang digunakan untuk mengevaluasi dan mendaftar secara ringkas kekuatan dan kelemahan (strength and weakness) yang ada pada suatu organisasi dalam lingkup internal. Matriks ini juga digunakan sebagai dasar untuk mengidentifikasi dan mengevaluasi hubungan antara kekuatan dan kelemahan dengan kenyataan yang terjadi pada organisasi tersebut dalam lingkup internal (Wijaya,2013). Terdapat lima tahapan yang dikembangkan pada matriks EFAS dan IFAS yakni sebagai berikut:

1. Membuat daftar faktor internal organisasi meliputi kekuatan dan kelemahan (lingkup internal), serta ncaman dan kesempatan (lingkup eksternal) dengan cukup spesifik.

2. Memberikan bobot pada masing-masing faktor. Bobot digunakan sebagai indikasi tingkat penting relative faktor terhadap keberhasilan perusahaan alam atau industry. Seluruh jumlah bobot yang diberikan pada semua faktor harus sama yaitu 1,0 adapun angka yang diberikan adalah mulai dari 0,0 (tidak penting) hingga 1,0 (paling penting).

3. Memberikan peringkat (rating) pada setiap faktor sebagai indikasi faktor tersebut menunjukan kelemahan atau kekuatan bagi perusahaan. Angka yang diberikan adalah 1 hingga 4 dengan keterangan kelemahan utama (peringkat $=1$ ) atau kelemahan minor (peringkat = 2), kekuatan minor (peringkat $=3$ ) atau kekuatan utama (peringkat $=4$ ). Perlu diperhatikan peringkat adalah berdasarkan perushaan sedangkan bobot berdasarkan industri.

4. Mengalikan masing-masing bobot pada faktor dengan peringkatnya untuk menentukan rata-rata dari masing-masing variabel.

5. Menjumlahkan nilai yang diperoleh masing masing variabel untuk menentukan total nilai tertimbang bagi organisasi.

Total rata-rata tertimbang berkisar antara terendah 1,0 dan tertinggi 4,0 dengan rata-rata 2,5 . Total rata-rata tertimbang dibawah 2,5 menggambarkan kondisi organisasi yang lemah secara internal, sementara total nilai diatas 2,5 mengindikasikan posisi internal organisasi yang kuat

\subsubsection{Matriks SWOT}

Menurut Rangkuti (2006), Matriks SWOT dapat menggambarkan secara jelas bagaimana peluang dan ancaman eksternal yang dihadapi perusahaan dapat disesuaikan dengan kekuatan dan kelemahan yang dimilikinya. Matriks ini dapat menghasilkan empat sel kemungkinan altenatif strategis. Sel pertama berisi daftar kekuatan perusahaan yang berhasil dibangun oleh manejemen dan sel kedua berisis daftar kelemahan yang ingin dihilangkan. Oleh karena itu sel pertama dan kedua secara berturut-turut disebut sel $S$ dan sel W. Sel ketiga berisi daftar peluang bisnis yang dimiliki pada masa sekarang dan yang akan datang dan sel keempat berisis daftar ancaman yang sedang dihadapi sekarang dan yang akan datang. Oleh karena itu sel ketiga dan keempat berturut-turut disebut sel $\mathrm{O}$ dan $\mathrm{T}$. 


\section{HASIL}

\subsection{Deskripsi Lokasi Penelitian}

Lokasi Ekowisata Mangrove terletak di kawasan Oesapa Barat, kota Kupang, Nusa Tenggara Timur Kupang. Destinasi ekowisata diresmikan dan di buka mulai bulan februari 2016. Hutan mangrove awalnya dikembangkan dengan adanya bantuan IFAD yakni organisasi yang bergerak di bidang pembangunan pesisir yang berpusat di Roma, Italia yang memberikan suntikan dana kepada pemerintah kota kupang dan di kelola dengan memberdayaan masyarakat setempat. Hutan mangrove ini memiliki luas kurag lebih seluas 40.695 hektar.

Gambar 2. Peta lokasi objek wisata Hutan Mangrove

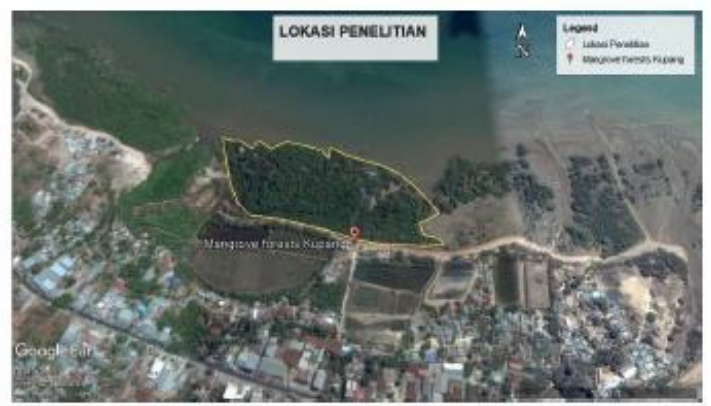

Gambar 3. Objek Wisata Hutan Mangrove

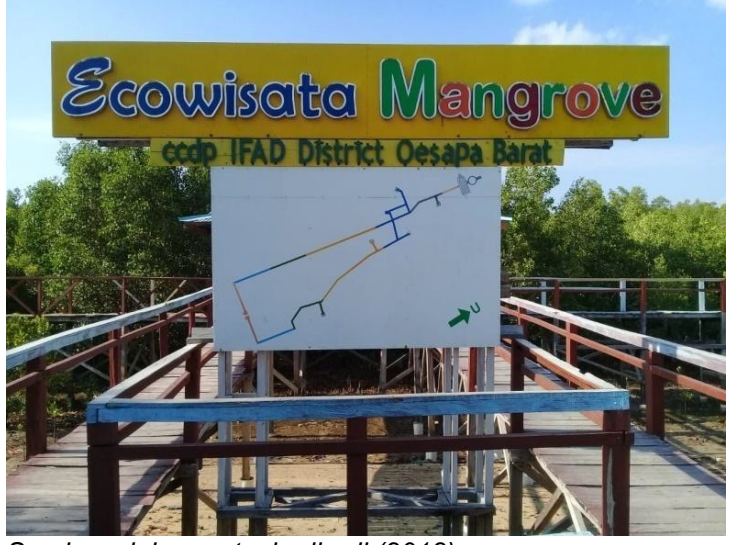

Sumber :dokumentasi pribadi (2018)

\subsection{Letak geografis}

Kelurahan Oesapa Barat masuk dalam wilayah Kecamatan Kelapa Lima terbentuk berdasarkan Peraturan Daerah Kota Kupang Nomor 6 Tahun 2006, terdiri dari 7 RW dan 19 RT. Selanjutnya pada tahun 2009 dengan mempertimbangkan pendekatan pelayanan, maka dilakukan pemekaran 3 wilayah RT menjadi 6 RT. Kelurahan Oesapa Barat mempunyai luas wilayah $6 \mathrm{KM}\left(6.000 \mathrm{M}^{2}\right)$, dengan batas-batas sebagai berikut :

Utara berbatasan dengan: TWAL Teluk Kupang Selatan berbatasan dengan: Kelurahan Tuak Daun Merah (TDM) dan Kelurahan Kayu Putih Timur berbatasan dengan: Kelurahan Oesapa
Barat berbatasan dengan: Kelurahan Kelapa Lima.

\subsection{Potensi ekowisata hutan mangrove oesapa}

Potensi wisata adalah berbagai sumber daya yang terdapat di sebuah daerah tertentu yang bisa di kembangankan menjadi atraksi wisata. Potensi wisata yang terdapat dikawasan objek wisata hutan mangrove oesapa adalah pemandangan alam hutan mangrove yang lebat dan luas, wisata air, pantai, tempat pembuatan perahu serta tambak garam yang dapat dijadikan atraksi wisata yang ada di destinasi tersebut. Hutan mangrove yang terdapat dikawasan pantai oesapa barat dapat dimanfaatkan sebagai sarana pembelajaran kepada wisatawan, pelajar, mahasiswa yang datang berkunjung, agar lebih mengenal alam dan meningkatkan kesadaran terhadap lingkungan hidup.

Gambar 4. Hutan Mangrove Oesapa

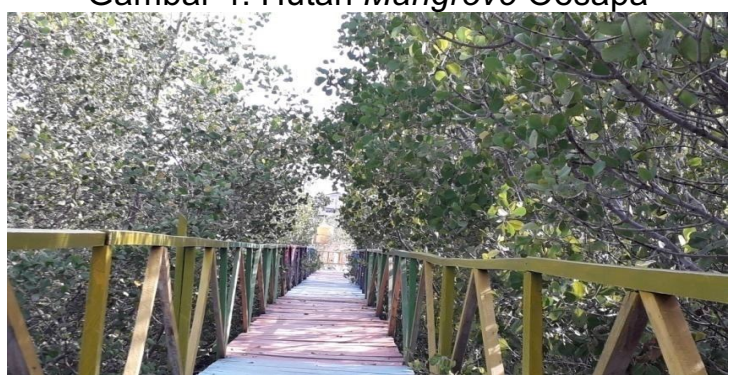

Gambar 5. Hutan Mangrove Oesapa

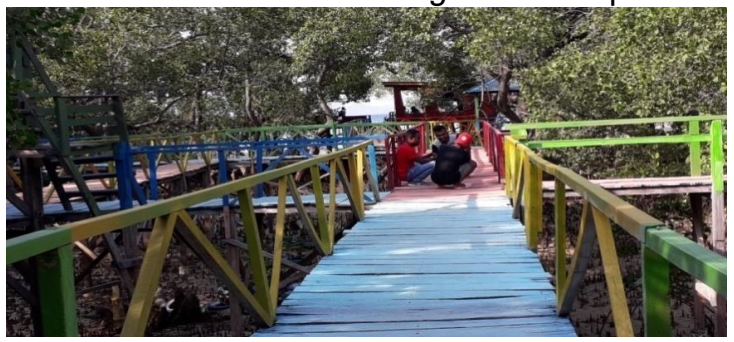

Gambar 6. Pantai Hutan Mangrove Oesapa

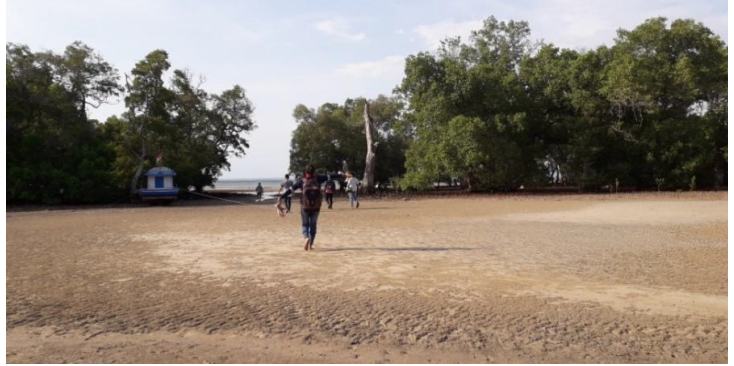

Gambar 7. Objek Wisata Hutan Mangrove 
STRATEGI PENGEMBANGAN EKOWISATA Novalina Sagala ${ }^{1 *}$, Imelda Regina Pellokila, SE.,MM²

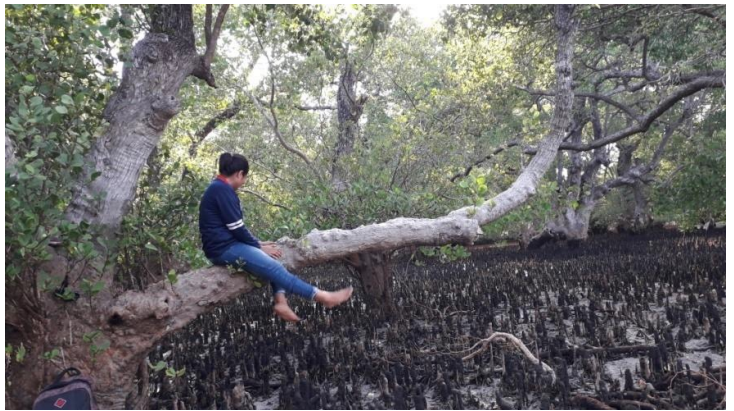

Gambar 8. Pantai Hutan Mangrove Oesapa

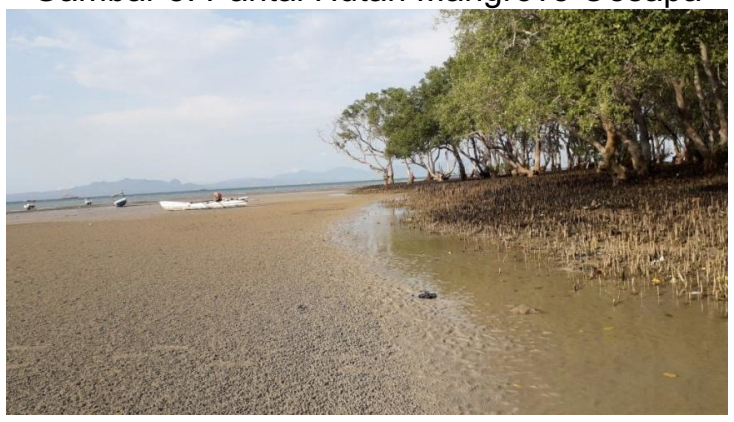

Gambar 9. Pantai Hutan Mangrove

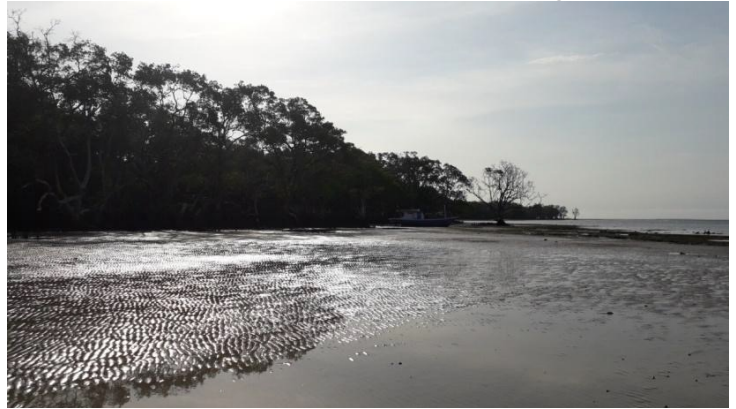

Gambar 10. Hutan Mangrove

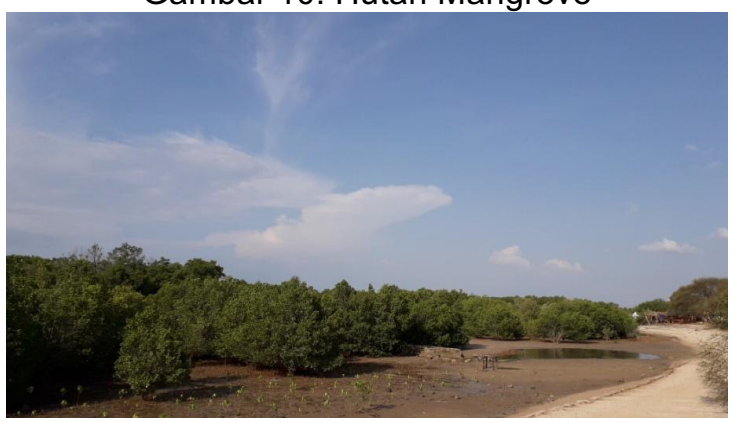

Sumer : Dokumentasi Pribadi (2018)

Gambar 11. Tambak Garam

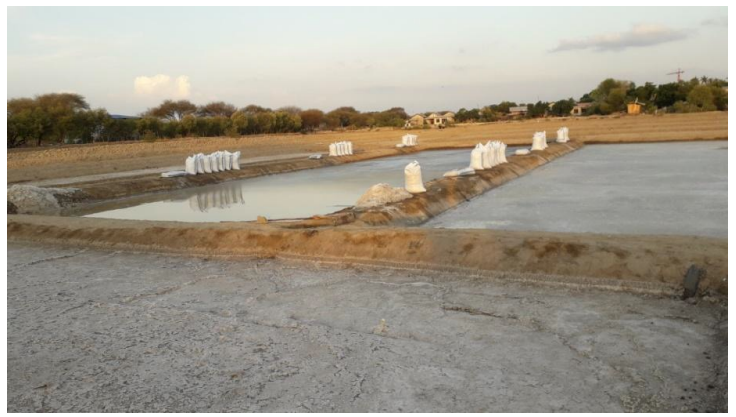

4.4 Analisis karakteristik responden
Pada penelitian selanjutnya mengenakan analisis kuantitatif menggunakan kuisioner yaitu strategi pengembangan pariwisata (sunaryo, 2013:159) dimana terdapat 5 komponen yang didalamnya terdapat 15 butir pertanyaan. Dengan jumlah seluruh responden penelitian sebanyak 75 wisatawan di daerah objek wisata hutan mangrove di kawasan oesapa barat. Karakteristik responden dalam penelitian ini adalah umur, jenis kelamin, pekerjaan dan pendidikan.

1. Karakteristik responden berdasarkan umur

Pada tabel dibawah ini dapat dilihat bahwa karakterstik responden berdasarkan umur diketahui terdapat 5 wisatawan dengan umur 17 tahun sebagai responden dengan persentase $6,7 \%$. pada umur 18 tahun sampai dengan 30 tahun yaitu 44 wisatawan sebagai responden dengan nilai persentase $58.7 \%$. sedangkan pada umur 31 tahun sampai dengan 40 tahun terdapat 26 wisatawan dengan persentase $34,6 \%$.

Berdasarkan karakteristik wisatawan di kawasan objek wisata hutan mangrove oesapa pada tahap ini dapat diketahui bahwa generasi muda cenderung lebih banyak untuk menyetujui kegiatan dalam strategi pengembangan ekowisata hutan mangrove.

Tabel 2. Karakteristik responden berdasarkan umur

\begin{tabular}{|l|l|l|}
\hline Valid & Frekuensi & Persentase \\
\hline 17 tahun & 5 & 6.7 \\
$18-30$ tahun & 44 & 58.7 \\
$31-40$ tahun & 26 & 34.6 \\
\hline Total & 75 & 100.0 \\
\hline
\end{tabular}

2. Karakteristik responden berdasarkan jenis kelamin

Data yang di peroleh berdasarkan kuisioner yang di isi oleh responden menunjukkan bahwa responden laki-laki memiliki frequensi 39 orang dengan persenatase $52 \%$ sedangka responden berjenis kelamin perempuan memiliki frequensi 36 dengan persentase $48 \%$. Jadi dapat disimpulkan bahwa mayoritas responden adalah dengan jenis kelamin laki-laki.

Tabel 3. Karakteristik responden berdasarkan

\begin{tabular}{|l|l|l|}
\multicolumn{3}{c}{ jenis kelamin } \\
\hline Valid & Frekuensi & Persentase \\
\hline Laki-Laki & 39 & 52.0 \\
Perempuan & 36 & 48.0 \\
\hline Total & 75 & 100.0 \\
\hline
\end{tabular}

3. Karakteristik berdasarkan pendidikan

Berdasarkan tabel di bawah ini dapat diketahui bahwa karakteristik berdasarkan pendidikan dengan jumlah responden 75 wisatawan. Dari jumlah tersebut responden memiliki jumlah terbanyak dengan pendidikan 
terakhir SMA, yaitu $60 \%$ selanjutnya yaitu diploma sebesar $21,4 \%$ dan pendidikan terakhir S1 sebesar $18 \%$.

Tabel 4. Karakteristik responden berdasarkan pendidikan

\begin{tabular}{|l|l|l|}
\hline Valid & Frekuensi & Persentase \\
\hline SMA & 45 & 61.9 \\
Diploma & 16 & 21.4 \\
S1 & 14 & 16.7 \\
\hline Total & 75 & 100 \\
\hline
\end{tabular}

4. Karakteristik berdasarkan pekerjaan

Berdasarkan tabel dibawah ini menunjukkan bahwa jumlah karakteristik pekerjaan responden pada destinasi wisata hutan mangrove oesapa paling banyak adalah mahasiswa dengan jumlah $49,3 \%$, sebagian dalah swasta $32 \%$, dan $18,7 \%$ masih berprofesi pelajar.

Tabel 5.Karakteristik berdasarkan pekerjaan

\begin{tabular}{|l|l|l|}
\hline Valid & Frekuensi & Persentase \\
\hline Mahasiswa & 37 & 49,3 \\
Swasta & 24 & 32,0 \\
Pelajar & 14 & 18,7 \\
\hline
\end{tabular}

\begin{tabular}{|l|l|l|}
\hline Total & 75 & 100,0 \\
\hline Sumber: data diolah spss 16
\end{tabular}

Sumber: data diolah spss 16

\subsection{Analisis SWOT}

Penelitian ini menggunakan metode kuantitatif lalu dianalaisis lebih dalam menggunakan pendekatan analisis SWOT yang digunakan untuk menyusun dan menghasilkan strategi pengembangan ekowisata pada hutan mangrove di kawasan pantai oesapa. Analisis SWOT digunakan untuk mengetahui gambaran kekuatan, kelemahan peluang dan ancaman yang ada dalam pengembangan ekowisata pada hutan mangrove di kawasan pantai oesapa.

A. Faktor Internal atau IFAS (Kekuatan dan Kelemahan)

Perencanaan strategi pengembangan untuk ekowisata hutan mangrove di kawasan pantai oesapa, dilakukan dengan langkah utama menganalisis kekuatan dan kelemahan yang ada dengan melihat kondisi lingkungan internal.

Tabel 6. Analisis Faktor Internal (IFAS)

\begin{tabular}{|c|c|c|c|}
\hline Faktor-faktor strategis & Bobot & Rating & Bobot $x$ Rating \\
\hline $\begin{array}{l}\text { Kekuatan: } \\
\text { 1. Memiliki potensi wisata hutan mangrove untuk } \\
\text { dikembangkan }\end{array}$ & 0.14 & 4.00 & 0,56 \\
\hline 2. Masih satu-satunya yang ada di kota kupang & 0.15 & 4.00 & 0,60 \\
\hline $\begin{array}{l}\text { 3. Memiliki lokasi strategis dan lingkungan yang } \\
\text { masih bersih }\end{array}$ & 0,13 & 3.00 & 0,39 \\
\hline 4. Memiliki keunikan atraksi wisata alam & 0,10 & 4.00 & 0,40 \\
\hline $\begin{array}{l}\text { 5. Keramahan dari masyarakat lokal terhadap } \\
\text { wisatawan. }\end{array}$ & 0,10 & 3.00 & 0,30 \\
\hline $\begin{array}{l}\text { 6. Memiliki hutan mangrove yang bisa dikelola } \\
\text { menjadi souvenir }\end{array}$ & 0,13 & 3.00 & 0,39 \\
\hline $\begin{array}{l}\text { 7. Adanya tambak garam sebagai atraksi wisata } \\
\text { lainya }\end{array}$ & 0,13 & 3.00 & 0,39 \\
\hline Sub total kekuatan & 0,88 & & 3,03 \\
\hline $\begin{array}{l}\text { Kelemahan : } \\
\text { 1. Kurangnya SDM dengan latar belakang di bidang } \\
\text { pariwisata }\end{array}$ & 0,03 & 2.00 & 0,06 \\
\hline $\begin{array}{l}\text { 2. Kurangnya keanekaragaman jenis ekosistem } \\
\text { mangrove. }\end{array}$ & 0,03 & 3.00 & 0,09 \\
\hline $\begin{array}{l}\text { 3. Kurangnya sarana dan prasarana pendukung } \\
\text { kegiatan ekowisata }\end{array}$ & 0,04 & 2.00 & 0,08 \\
\hline 4. Kurangnya kesadaran wisata. & 0,01 & 2.00 & 0,02 \\
\hline 5. Kurangnya atraksi wisata tambahan & 0,01 & 3.00 & 0,03 \\
\hline Sub total kelemahan & 0,12 & & 0,28 \\
\hline Total & 1,00 & & 3,31 \\
\hline
\end{tabular}

Sumber : data hasil penelitian diolah (2018)

Menentukan sumbu $\mathrm{x}$ dengan cara, skor total kekuatan - skor total kelemahan maka,

Sumbu horizontal $(x)=$ sub total kekuatan - sub total kelemahan

$$
\begin{aligned}
& =3,03-0,28 \\
& =2,75(\text { nilai sumbu } x)
\end{aligned}
$$

Jadi total dari faktor internal menunjukkan posisi internal yang kuat ekowisata hutan mangrove.

B. Faktor Eksternal atau EFAS (Peluang dan Ancaman) 
Langkah kedua dalam merencanakan strategi pengembangan yaitu menganalisis faktor-faktor eksternal berupa peluang dan ancaman yang mempengaruhi pengembangan ekowisata hutan mangrove di kawasan pantai oesapa

Tabel 7. Analisis Faktor-Faktor Eksternal (EFAS)

\begin{tabular}{|l|c|c|c|}
\hline \multicolumn{1}{|c|}{ Faktor-faktor strategis } & Bobot & Rating & Bobot $x$ Rating \\
\hline $\begin{array}{l}\text { Peluang: } \\
\text { a) Dukungan pemerintah terkait pengembangan } \\
\text { kawasan destinasi wisata }\end{array}$ & 0,16 & 4.00 & 0,64 \\
\hline b) Sektor pariwisata semakin berkembang & 0,18 & 3,00 & 0,54 \\
\hline $\begin{array}{l}\text { c) Penyuluhan sadar dari dinas pariwisata kota } \\
\text { kupang. }\end{array}$ & 0,15 & 3.00 & 0,45 \\
\hline $\begin{array}{l}\text { d) Dengan adanya lokasi strategis dapat dibukanya } \\
\text { usaha dibidang pariwisata. }\end{array}$ & 0,19 & 4.00 & 0,76 \\
\hline $\begin{array}{l}\text { e) Dapat menciptakan kesempatan kerja di bidang } \\
\text { pariwisata. }\end{array}$ & 0,18 & 4,00 & 0,72 \\
\hline $\begin{array}{l}\text { Sub total peluang } \\
\text { Ancaman: }\end{array}$ & $\mathbf{0 , 8 6}$ & & $\mathbf{3 , 1 1}$ \\
\hline dan mudah dijangkau selain hutan mangrove. & 0,03 & 2.00 & 0,18 \\
\hline b) Abrasi pantai & 0,04 & 1,00 & 0,04 \\
\hline $\begin{array}{l}\text { c) Masyarakat kurang tanggap dalam kegiatan } \\
\text { pariwisata baik dalam pengelolaan maupun } \\
\text { promosi }\end{array}$ & 0,07 & 2.00 & 0,14 \\
\hline Sub total ancaman & $\mathbf{0 , 1 4}$ & & $\mathbf{0 , 3 6}$ \\
\hline Total & $\mathbf{1 , 0 0}$ & & $\mathbf{3 , 4 7}$ \\
\hline
\end{tabular}

Sumber : Data Hasil Penelitian diolah (2018)

Sumbu vertical $(\mathrm{y})=$ sub total peluang - sub total ancaman

$$
\begin{aligned}
& =3,11-0,36 \\
& =2,75(\text { Nilai Sumbu Y) }
\end{aligned}
$$

Jadi sub total dari faktor eksternal menunjukkan posisi eksternal yang berpeluang besar di ekowisata hutan mangrove di kawasan pantai oesapa.

\section{Analisis Strategi SWOT}

Tabel 8.Analisis Strategi SWOT

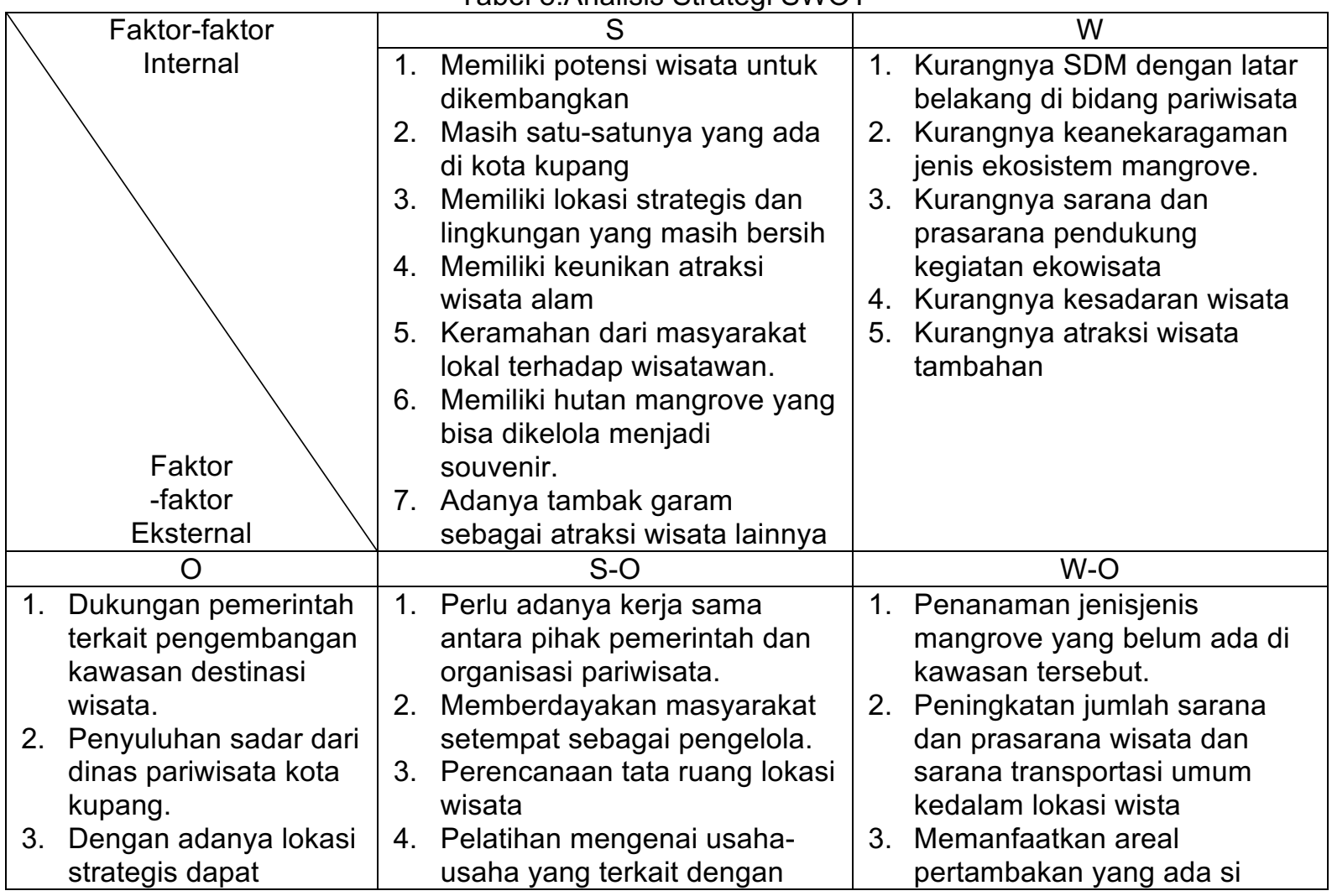




\begin{tabular}{|c|c|c|}
\hline $\begin{array}{l}\text { dibukanya usaha } \\
\text { dibidang pariwisata. } \\
\text { 4. Dapat menciptakan } \\
\text { kesempatan kerja di } \\
\text { bidang pariwisata. }\end{array}$ & $\begin{array}{l}\text { wisata terhadap SDM } \\
\text { setempat } \\
\text { 5. Perlunya publikasi mengenai } \\
\text { kawasan tersebut di } \\
\text { mediamedia social } \\
\text { 6. Perlunya pendanaan lebih } \\
\text { untuk menyediakan sarana } \\
\text { dan prasarana pendukung }\end{array}$ & $\begin{array}{l}\text { lokasi sebagai objek wisata } \\
\text { tambahan. }\end{array}$ \\
\hline$T$ & S-T & W-T \\
\hline $\begin{array}{l}\text { 1. Terdapat objek wisata } \\
\text { lainya yang lebih } \\
\text { menarik dan mudah } \\
\text { dijangkau selain hutan } \\
\text { mangrove. } \\
\text { 2. Abrasi pantai } \\
\text { 3. Masyarakat kurang } \\
\text { tanggap dalam } \\
\text { kegiatan pariwisata } \\
\text { baik dalam } \\
\text { pengelolaan maupun } \\
\text { promosi }\end{array}$ & $\begin{array}{l}\text { 1. Keunikan potensi hutan } \\
\text { mangrove yang berbeda } \\
\text { dengan objek wisata } \\
\text { lainya, pemanfaatan tambak } \\
\text { garam sebagai atraksi } \\
\text { tambahan. } \\
\text { 2. Penanaman jenis mangrove } \\
\text { penahan abrasi secara } \\
\text { berkelanjutan } \\
\text { 3. Perlunya dukungan } \\
\text { pemerintah dalam melakukan } \\
\text { sosialisasi dan pelatihan pada } \\
\text { masyarakat setempat. }\end{array}$ & 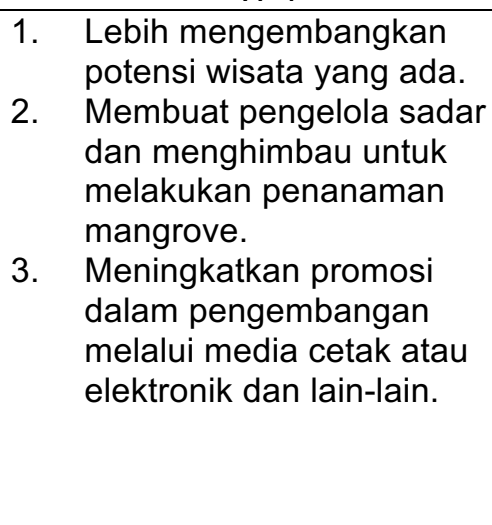 \\
\hline
\end{tabular}

Sumber : data hasil penelitian diolah (2018)

\subsection{Deskriptif Jawaban Responden Terhadap Indikator Strategi Pengembangan}

Berdasarkan data yang dikumpulkan dari hasil kuisioner yang disebarkan kepada wisatawan di kawasan ekowisata hutan mangrove pantai oesapa kemudian diolah menggunakan deskriptif persentase. Tujuanya untuk mengetahui strategi pengembangan pariwisata di ekowisata hutan mangrove berdasarkan indikator strategi pengembangan pariwisata. Untuk memudahkan analisis data hasil penelitian ini maka setiap indikator berdasarkan pertanyaan dengan dibuat tabulasi yang disesuaikan dengan teknis analisis data, sehingga untuk menilai jawaban responden pada setiap item pertanyaan digunakan nilai skor yang dikategorikan menjadi lima kategori yaitu (5) sangat setuju, (4) setuju, (3) ragu-ragu, (2) tidak setuju, (1) sangat tidak setuju.

Frekuensi jawaban adalah untuk mengetahui tinggi rendahnya jawaban responden dalam strategi pengembangan pariwisa melalui lima komponen indikator untuk memperoleh data-data yang diperoleh dari penelitian ini maka penulis membuat daftar pertanyaan/pernyataan pada kuisioner untuk dibagikan pada responden yang berjumlah 75 responden untuk dijawab sesuai dengan pendapat masing-masing responden sebagai berikut :

a. Objek dan daya tarik wisata (attraction)

a) Tanggapan responden mengenai pertanyaan/pernyataan 1 (satu).

Setujukah anda jika perlunya pengembangan hutan mangrove sebagai daya tarik utama objek wisata tersebut.
Tabel 9.

A1. Kategori, frekuensi dan persentasi jawaban responden untuk Objek dan daya tarik wisata (attraction)

\begin{tabular}{|l|c|c|}
\hline Valid & Frekuensi & Persentase \\
\hline Tidak Setuju & 2 & 2.7 \\
Ragu-Ragu & 8 & 10.7 \\
Setuju & 26 & 34.7 \\
Sangat Setuju & 39 & 52.0 \\
\hline Total & 75 & 100 \\
\hline
\end{tabular}

Sumber : data diolah spss 16

Berdasarkan tabel diatas menunjukkan bahwa sebagian besar responden dengan kategori sangat setuju dengan jumlah $52 \%$, $34,7 \%$ responden menyatakan dengan kategori setuju, 10,7\% responden masih ragu-ragu, $2,7 \%$ responden menyatakan tidak setuju jika perlunya pengembangan hutan mangrove sebagai daya tarik utama objek wisata tersebut. b) Tanggapan responden mengenai pertanyaan/pernyataan 2 (dua).

Kurangnya ragam jenis mangrove yang ada pada hutan mangrove.

Tabel 10.

A2. Kategori, frekuensi dan persentasi jawaban responden untuk Objek dan daya tarik wisata(attraction)

\begin{tabular}{|l|c|c|}
\hline Valid & Frekuensi & Persentase \\
\hline Ragu-Ragu & 2 & 2.7 \\
Sangat Setuju & 48 & 64.0 \\
Setuju & 25 & 33.3 \\
\hline Total & 75 & 100 \\
\hline
\end{tabular}

Sumber: data diolah spss 16

Berdasarkan tabel diatas menunjukkan bahwa $64 \%$ persentase masyarakat memberikan respon dengan sangat setuju, $33,3 \%$ meyatakan pada kategori setuju, dan 
2,7\% menyatakan kategori ragu-ragu bahwa kurangnya ragam jenis mangrove yang ada pada hutan mangrove di kawasan panai oesapa.

c) Tanggapan responden mengenai pertanyaan/pernyataan 3 (tiga).

Perlunya dilakukan penanaman ragam jenis mangrove guna memperbanyak jumlah biota yang ada pada hutan mangrove.

Tabel 11.

A3. Kategori, frekuensi dan persentasi jawaban responden untuk Objek dan daya tarik wisata (attraction)

\begin{tabular}{|l|c|c|}
\hline Valid & Frekuensi & Persentase \\
\hline Ragu-Ragu & 10 & 13.3 \\
Setuju & 35 & 46.7 \\
Sangat Setuju & 30 & 40.0 \\
\hline Total & 75 & 100.0 \\
\hline
\end{tabular}

Sumber: data diolah spss 16

Berdasarkan tabel diatas dapat diketahui bahwa $46,7 \%$ masyarakat menyatakan bahwa setuju, $40 \%$ menyatakan sangat setuju, dan $13,3 \%$ masyarakat menyatakan masih raguragu jika perlunya dilakukan penanaman ragam jenis mangrove guna memperbanyak jumlah biota yang ada pada hutan mangrove.

d) Tanggapan responden mengenai pertanyaan/penyataan 4 (empat).

Objek wisata hutan mangrove butuh atraksi wisata tambahan/pendukung lainya.

Tabel 12.

A4. Kategori, frekuensi dan persentasi jawaban responden untuk Objek dan daya tarik wisata (attraction)

\begin{tabular}{|l|c|c|}
\hline Valid & Frekuensi & Persentase \\
\hline Ragu-Ragu & 2 & 2.7 \\
Setuju & 38 & 50.7 \\
Sangat Setuju & 35 & 46.7 \\
\hline Total & 75 & 100.0 \\
\hline
\end{tabular}

Sumber: data diolah spss 16

Berdasarkan tabel diatas dapat diketahui bahwa $50,7 \%$ responden menyatakan bahwa mereka setuju, 46,7\% masyarakat menyatakan bahwa sangat setuju, sedangkan 2,7 responden lainya masih termasuk dalam kategori ragu-ragu jika objek wisata hutan mangrove butuh atraksi wisata tambahan/pendukung lainya.

b. Aksesibilitas (accessibility)

a) Tanggapan responden mengenai pernyataan/pernyataan 1 (satu).

Setujukah anda jika hutan mangrove sudah memiliki akses masuk yang layak ?

Tabel 13

B1. Kategori, frekuensi dan persentasi jawaban responden untuk Aksesibilitas (accessibility)

\begin{tabular}{|l|c|c|}
\hline Valid & Frekuensi & Persentase \\
\hline Ragu-Ragu & 7 & 9.3 \\
\hline
\end{tabular}

\begin{tabular}{|l|c|c|}
\hline Setuju & 21 & 28.0 \\
Sangat Setuju & 47 & 62.7 \\
\hline Total & 75 & 100.0 \\
\hline
\end{tabular}

Sumber : data diolah spss 16

Berdasarkan tabel diatas dapat diketahui bahwa $62,7 \%$ responden menyatakan bahwa mereka sangat setuju, $28 \%$ menyatakan bahwa mereka setuju, sedangkan 9,3\% mereka menyatakan bahwa mereka masih ragu ragu jika obejk wisata hutan mangrove sudah memilik akses yang layak.

b) Tanggapan responden mengenai pernyataan/pernyataan 2 (dua)

Hutan mangrove memiliki lokasi yang sangat mudah dijangkau.

Tabel 14.

B2. Kategori, frekuensi dan persentasi jawaban responden untuk Aksesibilitas (accessibility)

\begin{tabular}{|l|c|c|}
\hline Valid & Frekuensi & Persentase \\
\hline Setuju & 43 & 57.3 \\
Sangat Setuju & 32 & 42.7 \\
\hline Total & 75 & 100.0 \\
\hline
\end{tabular}

Sumber: data diolah spss 16

Berdasarkan tabel diatas menunjukkan bahwa $42,7 \%$ dengan kategori sangat setuju, sedangkan $57,3 \%$ menyatakan responya pada kategori setuju jika Hutan mangrove memiliki lokasi yang sangat mudah dijangkau.

c) Tanggapan responden mengenai pertanyaan/pernyataan 3(tiga).

Lokasi ekowisata hutan mangrove membutuhkan rambu-rambu petunjuk jalan baik pada jalan masuk maupun dalam lokasi wisata tersebut.

Tabel 15.

B3. Kategori, frekuensi dan persentasi jawaban responden untuk Aksesibilitas (accessibility)

\begin{tabular}{|l|c|c|}
\hline Valid & Frekuensi & Persentase \\
\hline Ragu-Ragu & 15 & 20.0 \\
Setuju & 35 & 46.7 \\
Sangat Setuju & 25 & 33.3 \\
\hline Total & 75 & 100.0 \\
\hline
\end{tabular}

Sumber: data diolah spss 16

Berdasarkan tabel diatas dapat diketahui bahwa 46,7\% dengan kategori setuju jika lokasi ekowisata hutan mangrove membutuhkan rambu-rambu petunjuk jalan baik pada jalan masuk maupun dalam lokasi wisata tersebut, sedangkan dengan kategori sangat setuju yaitu $33,3 \%$ dan $20,0 \%$ dengan respon ragu-ragu.

d) Tanggapan responden mengenai pertanyaan/pernyataan 4(empat).

Setujukah anda jika diadakannya transportasi umum untuk menuju lokasi wisata tersebut dari jalan utama seperti ojek dll guna mempermudah wisatawan yang tidak memiliki transportasi pribadi. 
Tabel 16.

B4. Kategori, frekuensi dan persentasi jawaban responden untuk Aksesibilitas (accessibility)

\begin{tabular}{|l|c|c|}
\hline Valid & Frekuensi & Persentase \\
\hline Setuju & 49 & 65.3 \\
Sangat Setuju & 26 & 34.7 \\
\hline Total & 75 & 100.0 \\
\hline
\end{tabular}

Sumber: data diolah spss 16

Berdasarkan tabel diatas menunjukkan bahwa $65,3 \%$ memberikan respon dengan kategori setuju, sedangkan 34,7\% memberikan respon dengan kategori sangat setuju. Hal ini menujukkan bahawa dibutuhkanya transportasi umum untuk menuju lokasi wisata tersebut dari jalan utama seperti ojek dll guna mempermudah wisatawan yang tidak memiliki transportasi pribadi.

c. Amenitas (amenities)

a) Tanggapan responden mengenai pertanyaan/pernyataan 1 (satu).

Hutan mangrove membutuhkan fasilitas penunjang seperti akomodasi, rumah makan,toko cendra mata dan lain-lain.

Tabel 17.

C1. Kategori, frekuensi dan persentasi jawaban responden untuk Amenitas (amenities)

\begin{tabular}{|l|c|c|}
\hline Valid & Frekuensi & Persentase \\
\hline Ragu-Ragu & 3 & 4.0 \\
Setuju & 31 & 41.3 \\
Sangat Setuju & 41 & 54.7 \\
\hline Total & 75 & 100.0 \\
\hline
\end{tabular}

Sumber; data diolah spss 16

Berdasarkan tabel diatas menunjukkan bahwa responden $54,7 \%$ dengan kategori sangat setuju, 41,3\% dengan kategori setuju, sedangkan $4 \%$ berada pada kategori ragu-ragu Hutan mangrove membutuhkan fasilitas penunjang seperti akomodasi, rumah makan,toko cendra mata dan lain-lain.

b) Tanggapan responden mengenai pertanyaan/pernyataan 2(dua).

Luas dan kondisi lahan parkir sudah sangat memadai.

Tabel 18.

C2. Kategori, frekuensi dan persentasi jawaban responden untuk Amenitas (amenities)

\begin{tabular}{|l|c|c|}
\hline Valid & Frekuensi & Persentase \\
\hline Setuju & 30 & 40.0 \\
Sangat Setuju & 45 & 60.0 \\
\hline Total & 75 & 100.0 \\
\hline
\end{tabular}

Sumber: data diolah spss 16

Berdasarkan tabel diatas menunjukkan bahwa $60 \%$ responden berada pada kategori sangat setuju, dan $40 \%$ pada kategori setuju jika luas dan kondisi lahan parkir sudah sangat memadai. c) Tanggapan responden mengenai pertanyaan/pernyataan 3(tiga).

Perlunya perbaikan dan pebambahan toilet yang baik dan bersih di lokasi objek wisata.

Tabel 19.

C3. Kategori, frekuensi dan persentasi jawaban responden untuk Amenitas (amenities)

\begin{tabular}{|l|c|c|}
\hline Valid & Frekuensi & Persentase \\
\hline Ragu-Ragu & 7 & 9.3 \\
Setuju & 40 & 53.3 \\
Sangat Setuju & 28 & 37.3 \\
\hline Total & 75 & 100.0 \\
\hline
\end{tabular}

Sumber: data diolah spss 16

Berdasarkan tabel diatas dapat di ketahui bahwa $54,7 \%$ setuju jika perlunya perbaikan dan pebambahan toilet yang baik dan bersih di dalam lokasi wisata, dan 37,3 berada pada katgori sangat setuju, sedangkan 9,3\% menyatakan jika respon mereka adalah raguragu.

d) Tanggapan responden mengenai pertanyaan/pernyataan 4(empat).

Perlu disediakan tempat evakuasi darurat. Tabel 20.

C4. Kategori, frekuensi dan persentasi jawaban responden untuk Amenitas (amenities)

\begin{tabular}{|l|c|c|}
\hline Valid & Frekuensi & Persentase \\
\hline Tidak Setuju & 2 & 2.7 \\
Ragu-Ragu & 4 & 5.3 \\
Setuju & 41 & 54.7 \\
Sangat Setuju & 28 & 37.3 \\
\hline Total & 75 & 100 \\
\hline
\end{tabular}

Sumber: data diolah spss 16

Berdasarkan tabel diatas dapat diketahui bahwa responden yang berada pada kategori sangat setuju ialah sebanyak 37.3 , dan yang menyatakan respon setuju adalah sebanyak $54,7 \%$,dan sisanya adalah responden yang menyatakan tidak setuju ada sebanyak 2,7\% dan ragu-ragu adalah sebanyak 5,3\%.

d. Fasilitas pendukung (ancillary service)

a) Tanggapan responden mengenai pertanyaan/pernyataan.

Setujukah anda jika diadakan fasilitas pendukung seperti ATM di area lokasi wisata? Tabel 21.

D1. Kategori, frekuensi dan persentasi jawaban responden untuk Fasilitas pendukung (ancillary service)

\begin{tabular}{|l|c|c|}
\hline Valid & Frekuensi & Persentase \\
\hline Ragu-Ragu & 23 & 30.7 \\
Setuju & 22 & 29.3 \\
Sangat Setuju & 30 & 40.0 \\
\hline Total & 75 & 100.0 \\
\hline
\end{tabular}

Sumber: data diolah spss 16

Berdasarkan tabel diatas menunjukkan bahwa responden yang berada pada kategori setuju jika diadakan fasilitas pendukung seperti 
ATM di area lokasi wisata adalah sebanyak $29,3 \%$, sedangkan responden yang ada pada kategori sangat setuju ada sebanyak 40.0, dan $30,7 \%$ ada pada kategori ragu-ragu.

b) Tanggapan responden mengenai pertanyaan/pernyataan 2(dua).

Terdapat pos keamanan umum di lokasi ekowisata hutan mangrove.

Tabel 22.

D2. Kategori, frekuensi dan persentasi jawaban respondeuntuk Fasilitas pendukung (ancillary service)

\begin{tabular}{|l|c|c|}
\hline Valid & Frekuensi & Persentase \\
\hline Ragu-Ragu & 2 & 2.7 \\
Setuju & 37 & 62.7 \\
Sangat Setuju & 36 & 34.7 \\
\hline Total & 75 & 100.0 \\
\hline
\end{tabular}

Sumber: data diolah spss 16

Berdasarkan tabel diatas dapat diketahui bahwa $62.7 \%$ setuju jika Terdapat pos keamanan umum di lokasi ekowisata hutan mangrove, $34,7 \%$ berada pada kategori sangat setuju,dan $2,7 \%$ menyatakan masih ragu-ragu.

c) Tanggapan responden mengenai pertanyaan/pernyataan 3 (tiga). Perlunya posko kesehatan di area wisata.

Tabel 23.

D3. Kategori, frekuensi, dan persentasi jawaban responden untuk Fasilitas pendukung (ancillary service)

\begin{tabular}{|l|c|c|}
\hline Valid & Frekuensi & Persentase \\
\hline Ragu-Ragu & 5 & 6.6 \\
Setuju & 23 & 30.7 \\
Sangat Setuju & 47 & 62.7 \\
\hline Total & 75 & 100.0 \\
\hline
\end{tabular}

Sumber: data diolah spss 16

Berdasarkan tabel diatas dapat diketahui bahwa $30,7 \%$ setuju jika terdapat posko kesehatan di lokasi ekowisata hutan mangrove, $62,7 \%$ berada pada kategori sangat setuju,dan $6,6 \%$ menyatakan masih ragu-ragu.

d) Tanggapan responden mengenai pertanyaan/pernyataan 4(empat).

Tersedianya sarana beribadah. Tabel 24.

D4. Kategori, frekuensi, dan persentasi jawaban responden untuk Fasilitas pendukung (ancillary service)

\begin{tabular}{|l|c|c|}
\hline Valid & Frekuensi & Persentase \\
\hline Setuju & 42 & 56.0 \\
Sangat Setuju & 33 & 44.0 \\
\hline Total & 75 & 100.0 \\
\hline
\end{tabular}

Sumber: data diolah spss 16

Berdasarkan tabel diatas dapat diketahui bahwa 56\% setuju jika terdapat posko kesehatan di lokasi ekowisata hutan mangrove, $44 \%$ berada pada kategori sangat setuju.

e. Kelembagaan (institution)

a) Tanggapan responden mengenai pernyataan/pertanyaan 1 (satu).
Dukungan masyarakat setempat sangat perlu dalam setiap inisiatif dalam strategi penembangan pada ekowisata hutan mangrove oesapa.

Tabel 25.

E1. Kategori, frekuensi, dan persentase jawaban responden untuk Kelembagaan (institution)

\begin{tabular}{|l|c|c|}
\hline Valid & Frekuensi & Persentase \\
\hline Setuju & 45 & 60.0 \\
Sangat Setuju & 30 & 40.0 \\
\hline Total & 75 & 100.0 \\
\hline
\end{tabular}

Sumber: data diolah spss 16

Berdasarkan tabel diatas dapat diketahui bahwa $60 \%$ setuju jika dukungan masyarakat setempat sangat perlu dalam setiap inisiatif dalam strategi penembangan pada ekowisata hutan mangrove oesapa., $40 \%$ berada pada kategori sangat setuju.

b) Tanggapan responden mengenai pernyataan/pertanyaan 2(dua).

Setujukah anda jika masyarakat perlu kerja sama dan terlibat dengan pihak-pihak terkait dalam strategi perencanaan pengembangan hutan mangrove oesapa.?

Tabel 26.

E2. Kategori, frekuensi, dan persentase jawaban responden untuk Kelembagaan (institution)

\begin{tabular}{|l|c|c|}
\hline Valid & Frekuensi & Persentase \\
\hline Setuju & 29 & 38.7 \\
Sangat Setuju & 46 & 61.3 \\
\hline Total & 75 & 100.0 \\
\hline
\end{tabular}
Sumber: data diolah spss 16

Berdasarkan tabel diatas dapat diketahui bahwa 38,7\% setuju jika masyarakat perlu kerja sama dan terlibat dengan pihak-pihak terkait dalam strategi perencanaan pengembangan hutan mangrove oesapa, $61,3 \%$ berada pada kategori sangat setuju.

c) Tanggapan responden mengenai pernyataan/pertanyaan 3 (tiga).

Masyarakat perlu terlibat bahkan jadi pelaku dalam kegiatan-kegiatan yang berhubungan dalam penegmbangan dan pengelolaan hutan mangrove.

Tabel 27.

E3. Kategori, frekuensi, dan persentase jawaban responden untuk Kelembagaan (institution)

\begin{tabular}{|l|c|c|}
\hline Valid & Frekuensi & Persentase \\
\hline Ragu-Ragu & 2 & 2.7 \\
Setuju & 48 & 64.0 \\
Sangat Setuju & 25 & 33.3 \\
\hline Total & 75 & 100.0 \\
\hline
\end{tabular}
Sumber: data diolah spss 16

Berdasarkan tabel diatas dapat diketahui bahwa $64 \%$ setuju jika masyarakat perlu terlibat bahkan jadi pelaku dalam kegiatan-kegiatan yang berhubungan dalam pengembangan dan 
pengelolaan hutan mangrove, $33,3 \%$ berada pada kategori sangat setuju, sedangkan 2,7 berada pada kategori ragu-ragu.

d) Tanggapan responden mengenai pernyataan/pertanyaan 4(empat).

Pemerintah perlu melakukan pelatihan,pengarahan bagi masyarakat dalam pengelolaan pariwisata.

Tabel 28.

E4. Kategori, frekuensi, dan persentase jawaban responden untuk Kelembagaan (institution)

\begin{tabular}{|l|c|c|}
\hline Valid & Frekuensi & Persentase \\
\hline Ragu-Ragu & 12 & 16.0 \\
Setuju & 48 & 64.0 \\
Sangat Setuju & 15 & 20.0 \\
\hline Total & 75 & 100.0 \\
\hline
\end{tabular}

Sumber: data diolah spss 16

Berdasarkan tabel diatas dapat diketahui bahwa $64 \%$ setuju jika pemerintah perlu melakukan pelatihan, pengarahan bagi masyarakat dalam pengelolaan pariwisata., $20 \%$ berada pada kategori sangat setuju, sedangkan 16 berada pada kategori ragu-ragu.

\section{PEMBAHASAN}

\subsection{Strategi Pengembangan Ekowisata Mangrove Dikawasan Pantai Oesapa Barat}

Strategi pengembangan ekowisata pada hutan mangrove oesapa barat melalui prinsipprinsip strategi pengembangan ekowisata, strategi pengembangan dengan pemerintah, masyarakat dan usaha pariwisata lainya belum terlihat maksimal. Hal ini disebabkan karena kesadaran wisata pada masyarakat dan pengelola dan pemanfaatan sumber daya alam yang tersedia belum maksimal. Melalui metode analisis SWOT dengan tujuan untuk mengetahui strategi terhadap pengembangan ekowisata pada hutan mangrove di kawasan oesapa barat. Dalam hal ini masyarakat sebagai pelaku utama dalam pengembangan ekowisata pada hutan mangrove pada semua garis baik itu dalam perencanaan, pelaksanaan, pemantau, maupun evaluator. Namun masyarakat sangat perlu adanya keterlibatan serta dukungan penting dari pemerintah dan komunitas pariwisata lainya yang terjalin kerja sama untuk pengembangan pariwisata berbasis masyarakat.

Berdasarkan analisis yang telah dilakukan untuk mengidentfikasi kekuatan, kelemahan, peluang, dan ancaman, dapat diketahui bahwa kekuatan dan peluang lebih banyak. Dari hal tersebut dapat diketahui bahwa stretegi yang diterapkan dapat digolongkan sangat menguntungkan. Pengembangan ekowisata hutan mangrove di kawasan pantai oesapa memiliki peluang dengan memanfaatkan kekuatan untuk pengembangan ekowisata hutan mangrove di kawasan pantai oesapa yaitu dapat menciptakan lapangan kerja baru khususnya di bidang ariwisata bagi masyarakat lokal.

Maka pengembangan ekowisata hutan mangrove oesapa barat dengan keterlibatan masyarakat lokal mulai dari anak muda sampai orang tua, diharapkan juga adanya kerja sama antarpemerintah dan pihak komunitas pariwisata lainya, sehingga pengembangan pariwisata baik potensi wisata maupun atraksi wisata lainya yang ada dapat berjalan maksimal.

\section{PENUTUP}

\subsection{Kesimpulan}

Kondisi potensi objek wisata hutan mangrove secara keseluruhan dari segi fisiknya masih perlu sentuhan, perhatian dan pembangunan yang lebih lagi, baik itu dari pihak pemerintah yang bersangkutan maupun dari pihak pengelola dan masyarakat setempat. Keterlibatan stakeholders dalam pengembangan-pengembangan ekowista , kualitas dan kuantitas SDM belum memadai, perlunya sosialisai dan pelatihan khusus bagi masyarakat stempat guna sebagai pengelola objek wisata, keterbatasan anggaran dari pemerintah untuk dikembangkan berdasarkan prinsip-prinsip pengembangan pariwisata.

Berdasarkan hasil analisis SWOT tentang strategi pengembangan ekowisata hutan mangrove dikawasan pantai oespa barat. Langkah yang dapat dirumuskan dengan menggunakan kekuatan dan memanfaatkan peluang yaitu adanya kerja sama pihak pemerintah dan komunitas pariwisata lainya yang memanfaatkan potensi yang tersedia. Memanfaatkan atraksi yang tersedia dan menambahkan atraksi pendukung, memberdayakan masyarakat lokal, dan memanfaatkan lokasi untuk dijadikan tempat usaha pariwisata.

\subsection{Saran}

a. Perlunya perbaikan serta peningkatan kualitas sarana dan prasarana seperti papan imformasi yang masih minim serta menambahkan fasilita di lokasi objek wisaata hutan mangrove ekowisata hutan mangrove di kawasan pantai oesapa barat.

b. Meningkatkan kualita dan kuantitas SDM yang memadai dalam hal melayani wisatawan dengan memberikan penyuluhan serta pelatihan mengenai kepariwisataan. Peningkatan promosi dan publikasi tentang objek wisata hutan 
mangrove oesapa barat melalui media cetak maupun media elektronik.

c. Mengoptimalkan pengembangan ekowisata hutan mangrove dikawasan pantai oesapa dengan menerapkan strategi pengembangan berdasarkan hasil analisis SWOT. Hal ini dapat dilakukan langsung dengan partisipasi masyarakat lokal dengan pemerintah serta usaha pariwisata untuk pengembangan potensi wisata yang tersedia. Atraksi pendukung yang telah tersedia perlu dikembangkan, diperlukan juga menambahkan atraksi pendukung lainya guna untuk menarik minat wisatawan.

d. Menetapkan visi dan misi pada ekowisata hutan mangrove dalam setiap kegiatan pariwisata serta memperioritaskan pengembangan pariwisata untuk bisa memanfaatkan potesi-potensi wisata yang ada sebagai salah satu pendapatan asli bagi masyarakat setempat.

\section{DAFTAR PUSTAKA}

Alfira, Rizky (2014). Identifikasi Potensi Dan Strategi Pengembangan Ekowisata Mangrove Pada Kawasan Suaka Margasatwa Mampie Di Kecamatan Wonomulyo Kabupaten Polewali Mandar. Skripisi, Tidak Diterbitkan, Universitas Hasanuddin, Makassar.

Borley, Laster.2015. .Bagian Satu Budaya dan Pariwisata Handbook. (20 06 2018)

Damanik, J. dan Weber, H.F. 2006. Perencanaan ekowisata. PUSPAR UGM dan Andi, Yogyakarta.

Feronika, F. 2011.Studi KesesuaianEkosistem Mangrove Sebagai Objek Ekowisata Di Pulau Kapota Taman Nasional Wakatobi Sulawesi Tenggara. Skripsi. Jurusan IImu Kelautan.Universitas Hasanuddin, Makassar.

Hidayatullah M. (2013). Keragaman Jenis Mangrove Di Nusa Tenggara Timur. Tidak diterbitkan.

Irwani, Gustina (2016). Strategi Pengembangan Wisata Berbasis Masyarakat Di Kawasan Gunung BunderTaman Nasional Gunung Halimun Salak. (16 06 2018)

Rangkuti, F. 2005. Analisis SWOT Teknik Membedah Kasus Bisnis. PT. Gramedia Pustaka Utama. Jakarta.

Sastrayuda, Gumelar S (2010). Hand Out Mata Kuliah Concept Resort And Leisure, Strategi Pengembangan Dan Pengelolaan Resort And Leisur.

Siagian, P. S. 2007. Manajemen Strategik. Jakarta: PT. Bumi Aksara.
Soerjono, Soekanto. 2015. Bagian Satu Budaya dan Pariwisata Handbook.(20 06 2018)

Sugi, Rahayu (2015).Pengembangan Pariwisata Berbasis Masyarakat (Community Based Tourism) Di Kabupaten Kulon ProgoDaerah Istimewa $\left.\begin{array}{llll}\text { Yogyakarta. } & (27 & 06 & 2018\end{array}\right)$ https://www.google.co.id/url?q=http://eprin ts.uny.ac.id/36336/1/Sugi\%20Rahayu_HB 2015.pdf

Sugiyono, 2010. Metode Penelitian Bisnis. Bandung: Alfabeta.

Sugiyono, 2012. Memahami Penelitian Kualitatif. Bandung: Alfabeta.

Suswantoro, G. (1997). Dasar-Dasar Pariwisata. Penerbit Andi. Yogyakarta.

Wardiyanta, (2006). Metode Penelitian Pariwisata. Penerbit : ANDI Yogyakarta.

Wira Pratama, Firman (2017). Identifikasi Potensi Dan Strategi Pengembangan Ekowisata Mangrove Pada Kawasan Wisata Tanarajae Kecamatan Labbakkang Kabupaten Pangkep. Skripsi, Tidak Diterbitkan, Departemen IImu Kelautan Fakultas IImu Kelautan Dan Perikanan Universitas Hasanuddin, Makassar.

Wiratna, Sujarweni 2014. Metodologi Penelitian. PUSTAKABARUPRES.

Yoeti, OA. 1996. Pengantar Ilmu Pariwisata. Angkasa Offset. Bandung.

Yoeti, O. A. 2000. IImu Pariwisata: Sejarah, Perkembangan dan Prospeknya. Jakarta: PT. Pertiga. 